Vol. 5 (1996): 203-207.

\title{
The effect of two pesticides (Vitavax-300 and Gaucho) on rhizobia and on the nodulation of four legumes
}

\author{
Pasi Miettinen' \\ Ministry of Agriculture and Forestry, Helsinki, Finland \\ Plutarco E. Echegoyen \\ Centro Agronómico Tropical de Investigación y Ensañanza, 7170 Turrialba, Costa Rica
}

\begin{abstract}
The application of seed-protecting pesticides is often a prerequisite for raising legumes in the tropics. However, these chemicals may influence the development of root nodule symbiosis. In the present study, high concentrations of Gaucho insecticide (imidacloprid) and Vitavax-300 fungicide (carboxin and captan) clearly inhibited the growth of root nodule bacterium under laboratory conditions. However, they did not effect to the nodulation or biomass production of Arachis pintoi, Arachis hypogaea, Mucuna pruriens or Desmodium ovalifolium raised in a green house in eastern Costa Rica. Explanations for these results are discussed.
\end{abstract}

Key words: Central America, fungicide, insecticide, leguminous crops, symbiosis 'Current address: Oy Finnagro Ab, Asematie 6 B, 01300 Vantaa, Finland

\section{Introduction}

Different types of fungi and insects cause great economic losses for the tropical agriculture. In particular, the nutrient-rich seeds of the legumes are frequently attacked. However, many pesticides which are used to reduce seed rot and seedling damping-off of the legumes, are also toxic to the rhizobia (Diatloff, 1970), the beneficial, nitrogen fixing root nodule bacterium of the leg- umes. Some pesticides reduce the amount of fixed $\mathrm{N}_{2}$ (Fisher, 1976) and some may impair or even prevent the root nodule development (Staphorst and Strijdom, 1976). The goal of the present investigation was to study the influence of two commonly used Central-American pesticides on the growth of rhizobia under laboratory conditions. In addition, the sensitivity of the root nodule formation of Arachis pintoi Pinto, Arachis hypogaea L., Mucuna pruriens L. and Desmodium ovalifolium Wall. to these pesticides was studied. 
Miettinen, P. \& Echegoyen, P.E.: Effect of two pesticides on rhizobia and nodulation of four legumes (Research Note)

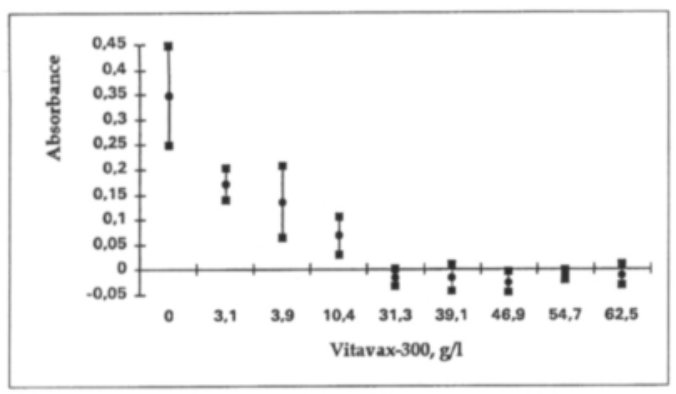

Fig. 1. Rhizobial growth at different Vitavax-300 (carboxin + captan) concentrations, measured as absorbance change at wavelength $605 \mathrm{~nm}$. Volume of the tubes was $14 \mathrm{ml}$, $\mathrm{n}=4$.

\section{Material and methods}

Two pesticide formulations were examined: Gaucho 70 WS, insecticide containing 70\%-m imidacloprid (manufactured in El Salvador), and Vitavax-300 fungicide, containing carboxin (2,3dihydro-5-carboxanilidi-6-methyl-1,4-oxathiin) $20 \%$-m and captan 20\%-m (manufactured by Uniroyal Chemical, United States). Specified peat inoculas for the legumes were provided by Departemento de Microbiología, University of Costa Rica. In addition, one rhizobium was isolated from the root nodules of $A$. pintoi from the experimental field of CATIE (Agricultural Education and Research Centre of Central America) for laboratory studies.

\section{Influence of the pesticides on the rhizobial isolate}

The pesticides $(100 \mathrm{~g})$ were poured into sterile water $(200 \mathrm{ml})$ and centrifuged at $5000 \mathrm{rpm}$ for 5 minutes to separate the inert compounds. The supernatant was dispensed into test tubes containing diluted (1:10) yeast-extract-mannitolbroth (YEM) described by Vincent (1970) to form a serial of increasing pesticide contents (Fig. 1 and Fig. 2). The tubes were inoculated with rhizobial isolate from $A$. pintoi. The inocu-

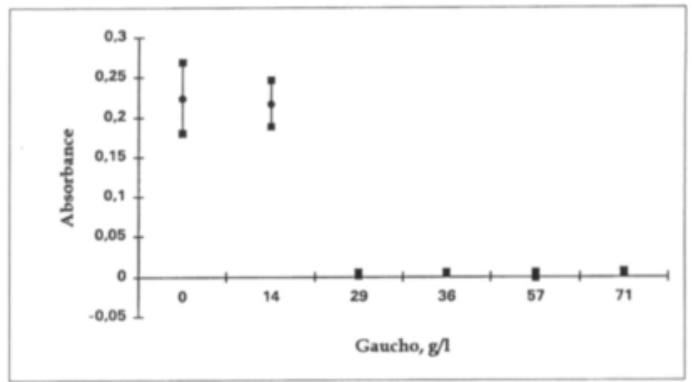

Fig. 2. Rhizobial growth at different Gaucho (imidacloprid) concentrations measured as absorbance change at wavelength $650 \mathrm{~nm}$. Volume of the tubes was $7 \mathrm{ml}, \mathrm{n}=3$.

lum had been grown for 8 days in $10 \mathrm{ml}$ of YEMbroth, then it was diluted in $90 \mathrm{ml}$ of sterile water and dispensed in $1 \mathrm{ml}$ doses to the test tubes. The tubes were kept for 8 days in an incubation chamber at $32^{\circ} \mathrm{C}$.

The growth (cell division rate) of the isolate was determined by using a spectrophotometer Perkin-Elmer Junior Model 35. The microbial growth was expressed as absorbances using the sterile media as reference.

\section{Influence of the pesticides on nodulation}

The seeds of the legumes were surface sterilised by immersing them in concentrated $\mathrm{H}_{2} \mathrm{O}_{2}$ for 1 minute and then rinsing them with sterile water three times. Then they were coated with Vitavax300 (approximately $2 \mathrm{~g} / 1 \mathrm{~kg}$ of the seeds), and Gaucho (approximately $5 \mathrm{~g} / 1 \mathrm{~kg}$ of the seeds) and finally with peat inoculums. The seeds were sown in half-litre-containers, which had been filled with ordinary nursery soil collected from the riverside forest. Uncoated seeds served as controls, and non-inoculated seeds were used to check the occurrence of native rhizobia in the soil. The number of seeds per container varied from 4 to 10 at the beginning of the experiment, depending on the seed size of the species. The containers were arranged in a completely randomised setup $(n=4)$ and irrigated with tap water. The seedlings were raised in an open green 
Vol. 5 (1996): 203-207.

Table 1. Total dry weight of the plants and root nodules at the end of the 10-week-raising- period in a green house in Costa Rica, Turrialba. Seeds were coated with pestices Vitavax-300 and Gaucho and inoculated with peat inocula. Uncoated seeds served as controls. Standard errors are given in parenthesis, $\mathrm{n}=4$.

\begin{tabular}{|l|l|l|l|l|}
\hline Legume & \multicolumn{2}{|l|}{ Total dry weight $(\mathrm{g})$} & \multicolumn{2}{l|}{ Dry weight of root nodules (g) } \\
\hline & $\begin{array}{l}\text { Pesticide- } \\
\text { treated }\end{array}$ & Control & $\begin{array}{l}\text { Pesticide } \\
\text { treated }\end{array}$ & Control \\
\hline Arachis pintoi & $10.15(1.96)$ & $12.6(2.18)$ & $0.11(0.035)$ & $0.17(0.07)$ \\
\hline Arachis hypogaea & $11.8(1.78)$ & $12.1(0.96)$ & $0.53(0.053)$ & $0.27(0.103)$ \\
\hline Desmodium ovalifolium & $3.7(1.27)$ & $3.85(1.48)$ & $0.055(0.038)$ & $0.04(0.041)$ \\
\hline Mucuna pruriens & $17.0(3.07)$ & $18.5(1.52)$ & $2.8(0.62)$ & $2.97(0.31)$ \\
\hline
\end{tabular}

house at CATIE, from October - December 1992 for 10 weeks.

The plants were harvested, and weighed with their roots at the end of the experiment. The root nodules were collected and dried separately. The total dry weight of the plants was determined by drying them overnight at $80^{\circ} \mathrm{C}$.

\section{Results}

High concentrations of Vitavax-300 clearly inhibited the growth of the rhizobia (Fig. 1). Three grams of Vitavax-300 in one litre of the nutrient broth was enough to halve the growth of the micro-organism. No growth was observed in the solutions in which the concentration of Vitavax300 exceeded $30 \mathrm{~g} / \mathrm{l}$.

The influence of Gaucho on the rhizobia was not as clear (Fig. 2). The Gaucho concentrations from 0.7 to $17.9 \mathrm{~g} / \mathrm{l} \mathrm{did}$ not inhibit the growth of the isolate. However, no clear growth was found in the tubes where the Gaucho concentration was $29 \mathrm{~g} / \mathrm{l}$ or more.

The treatment of the seeds with pesticides did not cause any notable changes in the dry mass production of the legumes (Table 1). The number and dry weight of the root nodules showed great variation in all treatments. Pesticides did not prevent nodulation.

\section{Discussion}

The low water-solubility of the investigated pesticides makes it very difficult to determine the exact concentrations of captan, carboxin or imidacloprid in the water-based experimental medium. However, it was clearly shown that high concentrations of Vitavax-300 and Gaucho were lethal to the rhizobial isolates in a liquid media under laboratory conditions. The deleterious influence of some pesticides to rhizobia has been reported earlier by Diatloff (1970) and Staphorst and Strijdom (1976). They have also found that strains of rhizobia from various origins differ in their relative sensitivity to pesticides.

Taking into consideration the clear effect of the pesticides on the rhizobia, it was quite surprising to notice that Vitavax-300 and Gaucho did not inhibit the nodulation of the investigated legumes. The concentrations of the pesticides inevitably diminished as the roots elongated, and thus their influence did not reach the nodulation zone. In addition, the exudes from the seeds and roots of the legumes possibly decreased the toxicity of the pesticides, as reported by Richardson (1966), who noticed that the toxicity of thiram may be negated by exudes from the seeds and roots of soybeans. It is also possible that, as the pesticides moved into the soil, they enhanced the growth of rhizobia by killing soil protozoa, which normally feed on rhizobia, as reviewed 


\section{AGRICULTURAL AND FOOD SCIENCE IN FINLAND}

Miettinen, P. \& Echegoyen, P.E.: Effect of two pesticides on rhizobia and nodulation of four legumes (Research Note)

by Alexander (1985). Lennox and Alexander (1981) reported a thiram-resistant Rhizobium phaseoli-strain, which induced an increment in nitrogen content on beans when their seeds were treated with that pesticide. They also noticed that protozoa proliferated if thiram was not applied to the seed, but the numbers of ciliates and flagellated protozoa were deleteriously influenced by the pesticide. Diatloff (1970) also reported good nodulation of legumes after treating the seeds with pesticides.

The uninoculated legumes were all nodulated by the native rhizobia present in the greenhouse soil. In the case of Mucuna pruriens, this was not expected since it had not been cultivated in the region before. However, Faria et al. (1989) came to the conclusion that the effective rhizobia of several legumes are widely distributed outside the geographical occurrence of their hosts, since legumes introduced from Australia and Central and North America nodulated abundantly in these sites without previous rhizobial inoculation in Brazil. In such cases, inoculation with laboratory-grown rhizobia is unnecessary.

Acknowledgements. We wish to thank The Academy of Finland and CATIE (Centro Agronómico Tropical de Investigación y Ensañanza) for their financial support for this study.

\section{References}

Alexander, M. 1985. Enhancing nitrogen fixation by use of pesticides: A review. Advances in Agronomy 38: 267281.

Diatloff, A. 1970. The effects of some pesticides on root nodule bacteria and subsequent nodulation. Australian Journal of Experimental Agronomy and Animal Husbandry 10: 562-567.

Faria S.M., Lewis G.P., Sprent, J.I. \& Sutherland J.M. 1989. Occurrence of nodulation in the Leguminosae. New Phytologist 111: 607-619.

Fisher, D.J. 1976. Effects of some fungicides on Rhizobium trifolii and its symbiotic relationships with white clover. Pesticide Science 7: 10-18.
Lennox, L.B. \& Alexander, M. 1981. Fungicide enhancement of nitrogen fixation and colonization of Phaseolus vulgaris by Rhizobium phaseoli. Applied and Environmental Microbiology 41: 404-411.

Richardson, L. 1966. Reversal of fungitoxicity of thiram by seed and root exudates. Canadian Journal of Botany 44: 111-112.

Staphorst, J.L. \& Strijdom, B.W. 1976. Effects on rhizobia of fungicides applied to legume seed. Phytophylactica 8: 47-54.

Vincent, J.M. 1970. A manual for the Study of Root Nodule Bacteria. IBP handbook 15. Blackwell Scientific Publications, Oxford and Edinburgh. 164 p. 
Vol. 5 (1996): 203-207.

\title{
SELOSTUS
}

\section{Kasvinsuojeluaineiden Vitavax-300 ja Gaucho vaikutus juurinystyräbakteerin kasvuun ja neljän palkokasvin nystyröitymiseen}

\author{
Pasi Miettinen ja Plutarco E. Echegoyen \\ Maa- ja metsätalousministeriö ja CATIE, Costa Rica
}

Tuhohyönteiset ja -sienet aiheuttavat vuosittain suuria taloudellisia menetyksiä kasvinviljelylle eri puolilla tropiikkia. Runsaasti ravinteita sisältävät palkokasvien siemenet saattavat tuhoutua kylvön jälkeen nopeasti, ellei niitä käsitellä kasvinsuojeluaineilla. Kasvinsuojeluaineet saattavat kuitenkin vaikuttaa ehkäisevästi palkokasvien juurinystyräsymbioosin kehittymiseen. Käsillä olevassa työssä tutkittiin kahden Väli-Amerikassa yleisesti käytetyn kasvinsuojeluaineen (fungisidi Vitavax-300: tehoaineina karboksiini ja kaptaani sekä insektisidi Gaucho: tehoaineena imidaklopridi) vaikutuksia maapähkinän juurinystyrästä eristettyyn ritsobiin sekä neljän eri palkokasvin juurinystyröiden kehittymiseen. Kumpikin tutkittu kasvinsuojeluaine keskeytti korkeina pitoisuuksi- na juurinystyräbakteerin kasvun laboratorio-olosuhteissa. Paksuilla kasvinsuojeluainekerroksilla kuorrutetuista siemenistä kehittyneet taimet nystyröityivät kasvihuoneessa kuitenkin yhtä hyvin kuin käsittelemättömät vertailutaimet. Kasvinsuojeluaineiden vaikutusalue ei siis ylettynyt juurinystyröiden muodostumisalueelle. Kirjallisuudesta löytyi viitteitä, joiden mukaan eräiden palkokasvien itävän siemenen alkeisjuuren eritteet saattavat neutraloida pestisidien tehoaineita. Kirjallisuusviitteiden mukaan pestisidien vaikutus saattaa myös kohdistua erityisesti ritsosfäärissä juurinystäbakteereita syöviin alkueläimiin, jolloin juurinystyräbakteerin lisääntymismahdollisuudet paranevat. 